\title{
Uşak Evlerinin Günümüze Yansıması ve Bireysel Söylemler
}

\section{The Reflections of Usak Houses on Modern Day and Individual Discourse}

\section{Muna Silav}

Doç., Ankara Hacı Bayram Veli Üniversitesi Güzel Sanatlar Fakültesi Kültür Varlıklarını Koruma ve Onarım Bölümü email: muna.silav@hbv.edu.tr (DORCID ID: https://orcid.org/0000-0003-3457-5059

\section{Naile Salman Cevik}

Doç. Dr., Ankara Hacı Bayram Veli Üniversitesi Güzel Sanatlar Fakültesi Heykel Bölümü email: naile.cevik@hbv.edu.tr BORCID ID: https://orcid.org/0000-0001-6448-1534

\section{Atıf (APA 6)/To cite this article}

Silav, M., \& Salman Cevik, N. (2019). Ușak evlerinin günümüze yansıması ve bireysel söylemler. Atatürk Üniversitesi Güzel Sanatlar Enstitüsü Dergisi, 43, 69-76. doi: https://doi.org/10.32547/ataunigsed.547462

Makale Gönderim Tarihi/Received: 01/04/2019

Makale Kabul Tarihi/Accepted: 29/09/2019

Makale Yayın Tarihi/Published: 26/10/2019

Review Article/Derleme Makalesi

\section{$\ddot{\mathbf{O z}}$}

Ușak ili, tarihsel süreç içerisinde önemli yerleșme yeri olarak merkezi konumda bulunmuştur. Bu merkezi konum, Uşak iline coğrafi ve kültürel anlamda önem kazandırmıștır. Uşak il merkezinde yer alan, kentin geleneksel yerleşme dokusunu yansıtan ve kent tarihinin yaşayan belgesi olan Ușak evleri, mimari birer kültürel mirastır. Kent kimliğinin şekillenmesinde önemli yeri olan bu evler, tasarımı ve malzemesi ile bulunduğu coğrafyayı yansıtan, sivil mimarlık yapıları olarak değerlendirilmektedir. Bu kapsamda, Uşak ilinin tarihsel ve kültürel kimliğini oluşturan önemli alanlardan biri olan tarihi evlerin esin kaynağı olarak araștırılması, belgelenmesi ve sanatsal açıdan yeniden yorumlanması biçiminde değerlendirilebilecek olan bu çalışma, geleneksel kentsel dokunun, toplum yapısının, yaşam biçiminin sürdürülebilirliği kavramlarından yola çıkarak, mekan-bellek-kültür ve aidiyet kavramları özelinde, Naile Salman Cevik'in ekslibrislerinde ve Muna Silav'ın suluboya çalışmalarında, özgün bireysel uygulamalar bakımından dikkat çekmektedir.

Anahtar kelimeler: Kültürel miras, Kentsel doku, Geleneksel yerleşim, Uşak evleri, Sanat

\begin{abstract}
The city of Usak has been a central location as an important settlement in the historical process. This central location has brought into geographical and cultural prominence to the city of Usak. Usak houses, locating in the city center of Usak, reflecting the traditional settlement texture of the city and being the living document of the city history, are the architectural cultural heritage. These houses, which have an important place in shaping the urban identity, are considered as civil architecture structures that reflect the geography it locates with design and material. In this context, this study, which can be evaluated in the garb of searching, documenting and reinterpreting in terms of art of the historical houses as the source of inspiration that are one of the important areas that constitute the historical and cultural identity of Uşak city, draws attention in the original individual applications of Muna Silav's watercolor works and Naile Salman Cevik's exlibris in terms of space-memory-culture and belonging concept based on the concepts of traditional urban texture, social structure, lifestyle sustainability.
\end{abstract}

Keywords: Cultural heritage, Urban texture, Traditional settlement, Usak houses, Art

\section{Giriş}

Barınma kavramı ile şekillenen ev, sosyal açıdan değerlendirildiğinde insanoğlunun temel gereksinimlerindendir. Bu temel gereksinim günümüze kadar birçok şekil değiştirmiştir. Zamanla ev kavramının değişimi, sadece fiziksel olarak değil sosyal, kültürel, ekonomik açıdan da birçok tanımı içinde barındırmaktadır. Toplumların inanç, kültür ve gelenek gibi somut olmayan değerleri, insanların temel yaşam alanı olan ev kavramı üzerinde önemli bir etkiye sahiptir. Bu etki, insan yaşamının gereksinimleri ve toplumsal değişiklik bakımından; çadır, otağ, konak, saray, köşk vb. isimlerle biçimlendirilmektedir. Bireyin yaşamı özelinde ve toplumların sosyal ve kültürel dinamiklerinin tanımlanması genelinde, ev kavramına yüklenen değerler, yapı kültürünün yanı sıra sanat anlayışını da beraberinde getirmiştir. Bu durum geçmişten günümüze sanat tarihi, mimari, iç mimari, peyzaj, plastik sanatlar gibi disiplinlerin yanı sıra ekonomik, teknolojik ve kültürel koşulların da değişimi ile farklı boyutlara taşınmıştır.

Ev, geleneksel kent görüntüsünün asıl bileşenlerinden biridir. Kavram ve yapı olarak ev, yaptıran ve yapanların ortak ürünü olmasının yanı sıra, toplumun ortak değerlerini ve estetik eğilimlerini ifade etmektedir (Kuban, 2017 , s. 1-3). Tarihi kentlerin korunması, değerlendirilmesi ve tarihi kentsel dokuları oluşturan bileşenlerin sürekliliğinin sağlanması için, yaşayan mekanlar olarak günümüzde yer alması önemlidir. Zaman içerisinde, yaşanılan fiziksel çevreye ait mekânsal çözümlemelerin incelenmesi ve mimari kimliğinin tanımlanması, topluma ait tarihi veriler olarak kabul edilmektedir. Bu kapsamda çalışma; taşınmaz kültürel miras kabul edilen ve sivil mimarlık örneği Uşak ili geleneksel evleri kapsamında oluşturulan, bireysel sanatsal söylemleri içermektedir. 


\section{Yöntem}

Bu çalışmada, betimsel araştırma yöntemi kullanılmıştır. Kültürel miras ve tarihi çevre bağlamında Uşak ilinin geleneksel tarihi kent dokusu ve ev kavramlarına yönelik ilgili alan yazın taranarak mevcut durum tespiti yapılmıştır. Elde edilen bulgular sonucunda geleneksel Uşak Türk evlerinin ekslibris ve suluboya resim tekniği kullanılarak bireysel sanatsal yorumları gerçekleştirilmiştir.

\section{Kültürel miras ve koruma}

Toplumların yaşadıkları yerleşimler, tarihi süreçte yaşantı ve kültür etkileşiminin yanı sıra zengin yerleşim şemaları, motif, renk, sanat anlayışları ile günümüze kadar gelmiştir (Taylan, 2013, s. ii). Kültür, toplumların değerlerini, kurallarını, davranış özelliklerini içeren insanların yaşama biçimi veya simgesel olarak aktarılan şemalar sistemi şeklinde tanımlanabilir. Gelecek nesillere aktarım, özellikle inşa edilmiş çevre ve ortamların kullanılışı yoluyla da olabilir (Ekim, 2012, s. 5).

Toplumlara ait kültürel değerler, geçmişe ait göstergeleri içermesi ve korunması gereken kültürel miras olmasının yanı sıra gelecek nesillere iletilmesi açısından da önemlidir. Bu toplumsal değerler, kentsel kimliğin/belleğin bir parçasıdır. Kent kimliğinin/belleğinin korunması, tarihsel kentsel dokunun yeniden canlandırılması, sosyal ve fiziki mekanların bütüncül olarak ele alınması açısından gerekliliği ön plana çıkmaktadır. Taşınmaz kültür varlıklarında fiziki, sosyal ve kültürel yapının korunduğu anlayış ile dünyada meydana gelen gelişmeler etken olmuştur. Bu gelişmeler, Venedik Tüzüğü, Birleşmiş Milletler Eğitim Bilim ve Kültür Kurumu (UNESCO), Uluslararası Anıtlar ve Sitler Konseyi (ICOMOS), Uluslararası Müzeler Komisyonu (ICOM) gibi kurumların oluşmasıyla Türkiye'de bu sürece katılmıştır (Özdemir Dağıstan, 2005'den aktaran Kurtar ve Somuncu, 2013, s. 36).

Tarihi kent dokusunun koruması ile ilgili, ICOMOS, Mimari Mirasın Koruma Bildirgesine göre "Kültürel miras, insanoğlunun toplumların ve toplumu oluşturan kültür gruplarının varlığının, kimliğinin ve sürekliliğinin simgesidir" (Kaderli, 2014, s. 37). Geçmişten günümüze kültürü oluşturan eylemler insan ile ilişkilidir. Kültürel miras, toplumun bakış açısıyla birlikte zaman ve mekân içinde şekillenmektedir. Bir kentin tarihi mekanları olarak kendini gösteren kültürel miras, kentin kültürel kimliğinin tanınmasına yardımcı olur (Tweed ve Shutherland, 2007'den aktaran Kurtar ve Somuncu, 2013, s. 36). UNESCO, 1976 yılında Tarihi Alanların Korunması ve Çağdaş Rolleri isimli belgede belirttiği üzere koruma; tarihi geleneksel alanların ve çevrelerinin tanımlanması, onarımları, bakımları ve günümüzde yeniden yaşatılmasıdır. Bu kapsamda yapı, çevresel bağlamda değerlendirilerek yeniden işlevlendirmeye yönelik çalışmalar gerçekleştirilmelidir (Zakar ve Eyüpgiller, 2015, s. 35). Kentlerin kimliğinin ortaya çıkarılmasında, yitirilmiş olan mekân ile bağlantının kazanılması, eski kent dokularını koruma çalışmaları uzun yıllardır sürdürülmekte ve bu süreç ile birlikte kentsel sit alanlarında kültürel mirası koruma çalışmaları gerçekleştirilmektedir (Kurtar ve Somuncu, 2013, s. 36).

\section{Ușak ilinin tarihi süreci}

Tarih boyunca Uşak ili çok sayıda uygarlığa ev sahipliği yapmıştır. Neolitik Dönemden itibaren yerleşmelerin bulunduğu bu bölgede, kalkolitik ve ilk tunç çağına ait yerleşmelerin devam ettiği görülmektedir. Batı ve Orta Anadolu'yu birbirine bağlayan Uşak ili, kültürel, ticari ve askeri yönden önemli bir bölgede yer almaktadır. Eskiçağ tarihi ile ilgili bilgiler, bölgeyi ziyaret eden seyyahlardan öğrenilmiştir. Bu seyyahlar, günümüze bölgede yer alan antik kentlerle ilgili bilgileri yazıtlardan, tarihi kalıntılardan ve sikkelerden yararlanarak aktarmışlardır. Bölgeden çıkarılan yazıtlar, Uşak’ta bulunan antik kentler hakkında doğru bilgilendirmenin yapılmasını sağlamıştır (Karahan, 2015, s. 1-3). Zengin kültürel dokuya sahip olan Uşak ilinde (Blaumdus, Selçikler (Sebaste), Güre) Hellenistik ve Roma Dönemi'ne ait kentlerin yanı sıra hanlar, hamamlar, köprüler, tarihi evler gibi çok sayıda sivil mimari yapısı yer almaktadır (T.C. Orman ve Su İşleri Bakanlığı, 2013, s. 42).

Solak’a (2001) göre Uşak ilinde bulunan yerleşimler M.Ö. 4000 yilına kadar tarihlenmektedir. Hititlerin, Friglerin, Lidyalıların, Perslerin, Makedonya Kralı Büyük İskender'in, Romalılar ve Bizans egemenliğinden sonra Selçuklu Sultanı II. Kılıçarslan Dönemi’nde kent, Türk hakimiyetine girmiştir. Osmanlı Beyliğinde (1390’lı yıllarda) Kütahya sancağına bağlı olan Uşak, Cumhuriyet döneminde 1953 yılında vilayet olana kadar idari yapısını bu şekilde devam ettirmiştir.

\section{Ev kültürü, Ușak evleri}

Kuban (2002), geleneksel Türk ailesinin yaşam kültürü ve törelerine uygun şekil ve plan özelliklerine sahip gereksinimlerine cevap veren, geleneksel Türk evinin oluşumunu Anadolu'daki toplum hayatı ile açıklanabileceğini belirtmektedir. Anadolu toprakları, Neolitik dönemden itibaren gelişen ve değişen ev yapısına sahiptir. Çatalhöyük antik yerleşkesinde görülen ve kent oluşturacak kadar çok sayıda bulunan, birbirine bitişik yerleşme düzeninde, girişlerin damlardan sağlandığı, kapısız kerpiç evler; korunma ve sığınma gereksinimine yanıt vermektedir. Tarihi süreçte bu mekanlar, önce odalar sonra bir kat daha eklenerek hayvancılığın ön plana çıkmasıyla avlular şeklinde ortaya çıkmıştır. Bu yerleşkeler de içgüdüsel olarak yapılan mimari çözümler, 
günümüzde de izlerini taşımaktadır (Uysal, 2007). Ev, Çatalhöyük evlerinde olduğu gibi, toplum ve kullanıcı gereksinimlerinin karşılandığı en önemli yaşam alanıdır. Zaman içinde insanlar barınmayı mimari faaliyete dönüştürürken, yaşadığı coğrafyanın, iklimin, kültürün ve geleneklerinin özelliklerini bu yapılara yansıtmıştır (Küçükerman, 1995, s. 26).

Geleneksel Türk Evi, Osmanlı Devleti’nin sınırları içinde (Rumeli ve Anadolu Bölgelerinde) yer alarak özgünlüğünü korumuştur. Türk evinin özgünlüğünü oluşturan özellikler, bulunduğu coğrafyanın iklim ve tabiat şartları ile şekillenerek birbirinden farklı yapıda meydana gelmiştir. Bu yapıdaki farklar, yöresel malzeme ve yerli geleneklerin etkisinden ortaya çıkmıştır (Eldem, 1984). Geleneksel kentlerde kimlik kazandıran sokaklar ise, kent dokusu ve toplumsal içeriği arasındaki ilişkinin sonucunda şekillenmektedir. Geleneksel sokaklar, insan tarafindan yapılmış çevrenin özelliklerini ve tarihi bir dönemi belgeleyen niteliktedir (Kuban, 2017, s. 171). Günümüz mimarisinde ise, kütlenin önem kazanması, sokak düzenini bozduğu için eleştirilmiştir. Geleneksel Türk evinde ise sokak düzeni bozulmadan, iç ve dış mekânın net olarak ayrılmadığı ve devamlılık için yapının sokak ile bütünleşmesi gerçekleşmektedir. Türk evlerinde, sokak ve bahçe arasında görsel mahremiyet kavramı, yüksek duvarlar ile sağlanmaktadır (Yürekli ve Yürekli, 2007'den aktaran Ekim, 2012, s. 12-13).

Osmanl1-Türk kentlerinin özellikleri ve geçirdiği değişim sürecinde Uşak ili, Türklerin eline geçtiği 14. ve 19. yüzyıl arasında, Osmanlı şehir yapısının özelliklerini taşımaktadır. Osmanlı şehirlerinin karakteristik özelliği Uşak ilinde de görülmektedir. Kent merkezini oluşturan Ulu Cami, çevresinde yer alan çarşı, bunun etrafındaki evler ve bu alanların bir araya gelmesiyle gelişen sokaklar ve mahallelerden meydana gelmektedir (Gürboğa, 1999, s. 23).

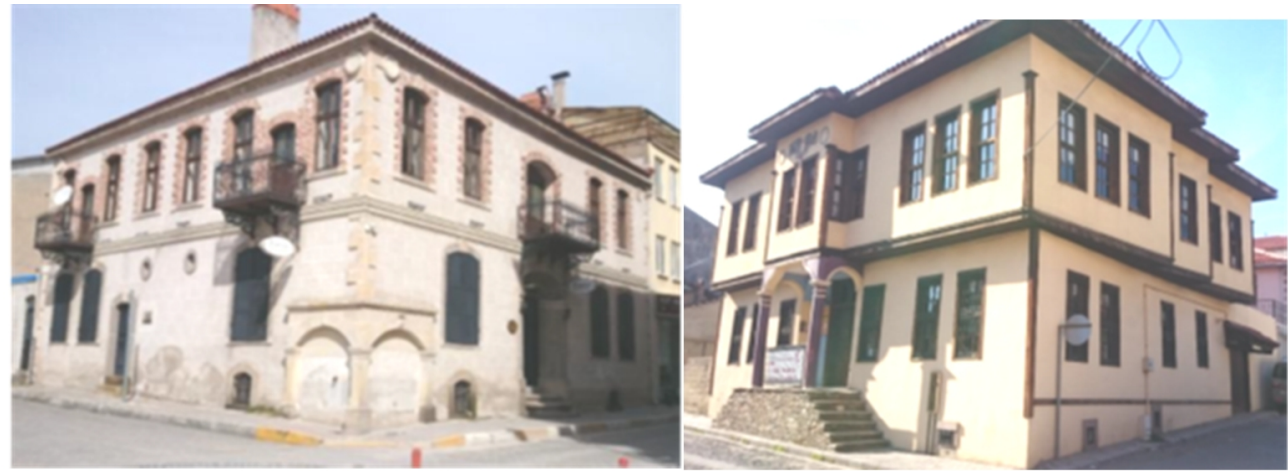

Görsel 1. Geleneksel Uşak evleri 1

Kurtuluş Savaşı'ndan sonra Uşak ili kent dokusunda, en erken tarihli konut örneği 19. yüzyıl ortalarına ait olmakla birlikte, günümüze ulaşan geleneksel evler Aybey mahallesinde belgelenmektedir.1894 y1lı yangını ile 11 mahallenin tamamen yok olduğu şehirde, yangından sonraki imar faaliyetleri ile kullanımı devam eden evler mimari açıdan Aybey mahallesindekiler ile büyük farklar da göstermemekle birlikte, 20. yüzyılda inşa edilmiş konutlarda malzeme olarak taş ve tuğla kullanılmıştır (Sayan, 1997, s. 18-19). Uşak’ta, Anadolu Türk konut mimarisinde olduğu gibi çoğunlukla iki katlı evler görülmektedir. Zemin katlar günlük ve kışlık ihtiyaca yönelik düzenlenmiş, evin asıl planını meydana getiren birinci katlar ise yaşam alanı olarak kullanılmıştır. Geleneksel Uşak evlerinin planlarında, Anadolu Türk konut mimarisinde bulunan, haremlik-selamlık bölümlerine rastlanmamaktadır. $\mathrm{Bu}$ ev planlarında sofa ise, konumuna göre dış sofalı ve iç sofalı plan tipi olarak gözlemlenmektedir. Evlerin cephe düzenlemesi sade olup, arsanın konumuna göre ya da sokağa göre şekillenmiştir. Ayrıca özellikle simetri ön planda tutulmuştur. Çıkma, silme, giriş açıklığı ve pencere sıraları ev cephelerine hareket sağlamaktadır (Sayan, 1997, s. 99-124). Uşak tarihi kent dokusunun korunmasında kültür mirası niteliğinde olan bu evlerin, özgün yerleşim dokusunu ve geleneksel mimari karakterini kaybetmeden günümüze kadar ulaştığı gözlemlenmektedir.

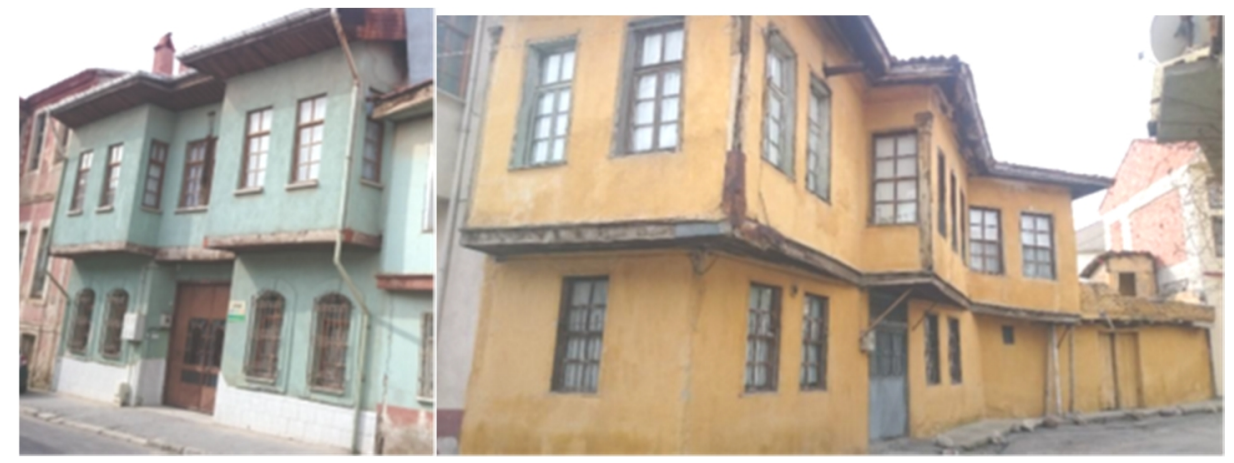

Görsel 2. Geleneksel Uşak evleri 2 


\section{Kültürel miras ve günümüze yansımaları üzerine bireysel söylemler}

\subsection{Naile Salman Çevik’in ekslibris (exlibris) çalışmaları}

Uluslararası alanda hızla yaygınlaşan kavramsal sanat, 1960 sonrasında gelişen tüm akımların yolunu açmıştır (Antmen, 2008, s. 196). Çağdaş sanat anlayışında ortaya çıkan yaklaşımlar ise sanat disiplinlerinin birbirini etkilediğini, önemli olanın estetik duyarlılık olduğunu ve ortaya çıkan sanat nesnelerinde kullanılan malzemenin ne olduğundan çok, içeriğin önem kazandığını göstermiştir. Günümüzde plastik sanatların değişik alanlarında görülen pek çok eser ya da etkinliğin algılanmasında, artık geleneksel anlamda bir görüntü algılaması yetmemekte, bunlar dayandıkları düşünce ve yorumlarla değer kazanabilmektedir (Akdeniz, 1995, s. 9-10). Baskıresim bugünkü anlamıyla çağa uygun ve toplumun modernizm ile birlikte ulaştığı noktada sanat eserlerine yeni bir görünüm sağlamayı başarmıştır (Yalçın, 2012, s. 58). Çağdaş sanatta baskıresmin yerinin ve öneminin, teknolojik gelişmelere verilen cevapla, geleneksel ve çağdaşla birlikte kurulan ve değişken benzersiz bir hareketlilik ile ortaya koyulacağı düşünülmektedir (Fırınc1, 2013, s. 13)
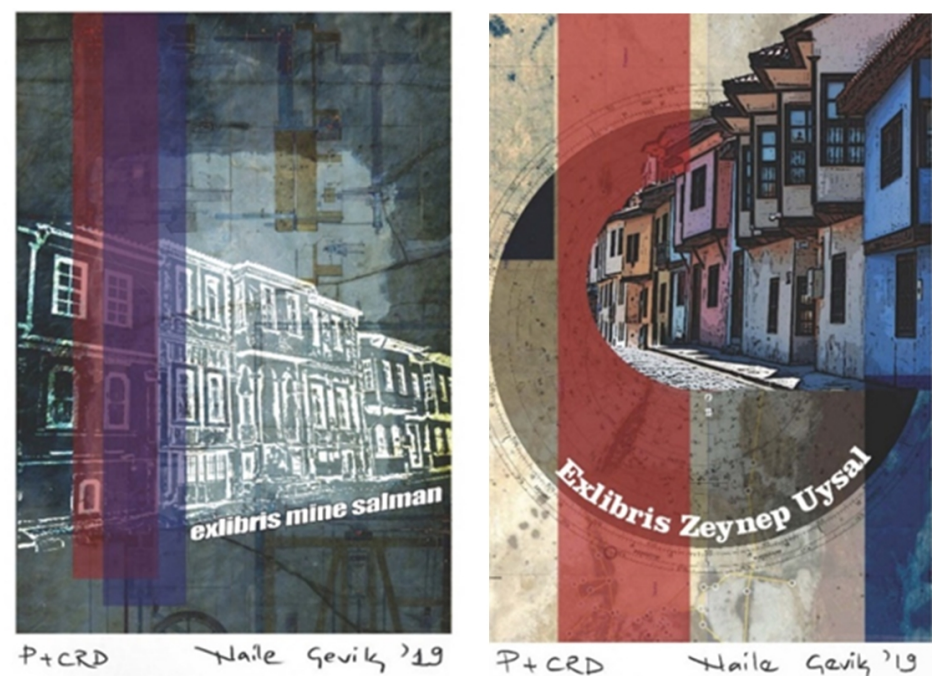

Görsel 3. Naile Salman Çevik, ekslibris, 2019

Sanat tarihine baktığımızda baskı resmin tarihini, yazının (M.Ö. 3000) ve kâğıdın (M.S. 105) bulunmasından sonra olduğunu görmekteyiz. Bilinen ilk baskı M.S. 868 yıllarına aittir. Kutsal inancı tasvir eden bu dönemin ağaç baskılarında, sanatsal bir kimlik olmamasına karşın bu çalışmalar erken dönem halk sanatı eserleri olarak daha sonraki uygulama ve tekniklerin gelişiminde önemli rol oynamışlardır. Doğu'da gelişen bu uygulama, ticari ilişkilerin gelişimi ile batı kültürüne yayılmıştır. Bu sayede 15.yüzyıldan itibaren plastik sanatların içinde yer alan özgün baskıresim sanatı, resim çoğaltma tekniği olarak Avrupa'da da kullanılmaya başlanılmıştır (Ayan, 2007, s. 22-23). Günümüzde baskıresim teknikleri; Mono Baskı (Monoytpe): Ağaç ve Linol Baskı (Yüksek Baskı), Gravür (Çukur Bask1), Taşbaskı-Litografi/Litography (Düz Bask1) ve Serigrafi/Silk-Screen (Elek Bask1) olarak sinıflandirılmaktadır.
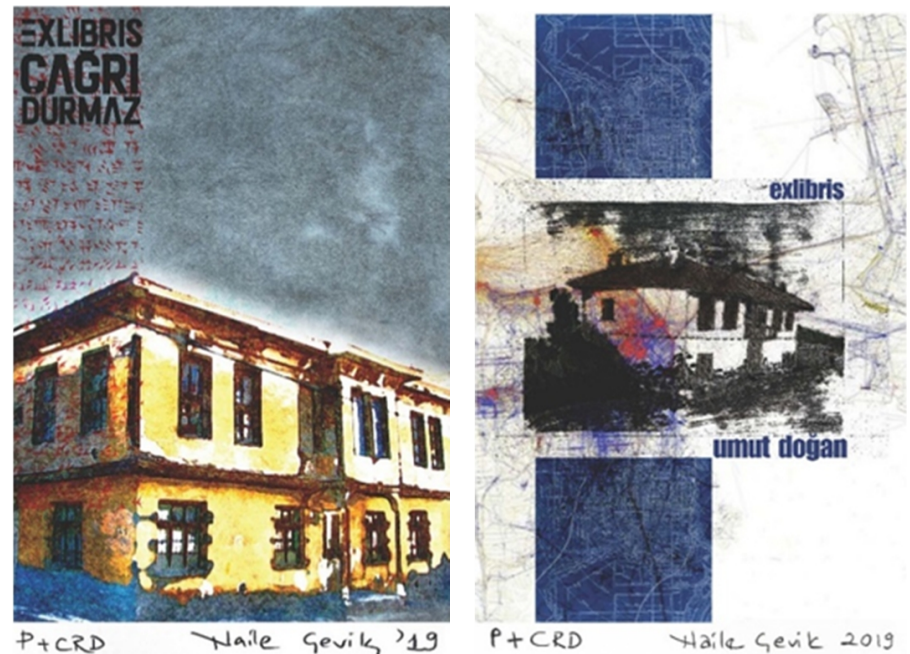

Görsel 4. Naile Salman Çevik, ekslibris, 2019 
Sözcük olarak ekslibris (exlibris) “...’nın kitabı”, “...’nın kitaplığına ait” veya “...’nın kütüphanesinden” anlamına gelir ve latince bir kelimedir (Severin, 1949, s. 7). Günümüze kadar çeşitli işlevler kazanmış olan ekslibris, kitapseverler tarafından kitapların iç kapağına yapıştırılan, üzerinde kitap sahibinin adı ve ilgili veya değişik konularda resimlerin bulunduğu küçük boyutlu özgün yapıtlardır (Kaynar, 2006, s. 4). Pektaş’a (2014) göre ekslibris, kitabın kartviziti ya da tapusudur. Ekslibrisler kitaptaki işlevinin dışında da bir sanatsal değere sahiptir. $\mathrm{Bu}$ sebeple özgün bir grafik ve resim çalışması olarak sergilenebilmekte ve koleksiyonlara girebilmektedir.

Matbaanın icadı kitapların çok sayıda basılıp yaygınlaşmasını, kitap çeşidinin çoğalmasını, kitaplıkların oluşumunu sağlamış ve ekslibrise olan gereksinimin artmasına da yol açmıştır (Kaynar, 2006, s. 8). Bir anlamda sahiplenme ve aidiyet kavramlarını da içinde barındıran ekslibris üretimleri zamanla sanatsal kurgu kazanarak işlevselliklerinin yanı sıra artistik bir anlam da kazanmışlardır. Bu durum sayesinde sadece kitapların etiketlenmeleri sağlanmamış aynı zamanda sergilerle, koleksiyonlarla ve satışlarla artarak çoğalan nesnel bir süreçte de ekslibrislerin estetik/kültürel kazanımlar da sağlaması söz konusu olmuştur.
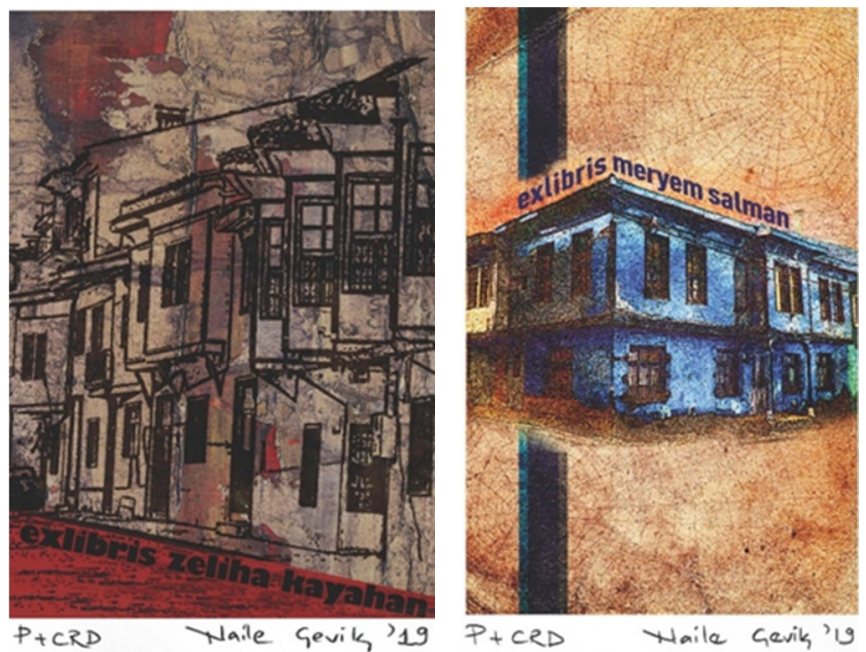

Görsel 5. Naile Salman Çevik, ekslibris, 2019

Bu anlamda sanatsal bir uygulama alanı olan ekslibris üretimleri yüksek baskı, çukur baskı ve düz baskı gibi birbirinden farklı baskıresim teknikleri ile de çoğaltılabilmektedir. Bu tekniklerin yanı sıra çağımızda bilgisayar aracılığ 1 ile uygulama alanı bulan özgün ekslibris uygulamaları da yer almaktadır. Özellikle bilgisayar aracılığ yapılan bu özgün tasarımların dijital baskı yöntemleri kullanılarak üretilmesi maliyet ve zaman açısından kolaylık sağlamasının yanı sıra ekslibris üretimlerinde de sanatçı, izleyici ve kitap sahibi arasında yeni bir üretim şeklini de ortaya koymuştur. Bu üretim şekli ulusal ve uluslararası yarışmalar, sergiler kapsamında kabul görerek özellikle ekslibrisin yaygınlaşmasında önemli bir rol üstlenmiştir.

Çalışmanın bu bölümünde kültürleri tanımada ve tanıtmada bir aktarım nesnesi olarak özgün ekslibris uygulamalarının oluşturulması, özellikle tarihi ve kültürel bir miras niteliği taşıyan Uşak evlerinin plastik bir dille gelecek nesillere aktarılması amacını yansıtmaktadır. Naile Salman Çevik'in özgün ekslibris uygulamaları değerlendirildiğinde genel anlamda kültürel miras ve özel anlamda geçmişte ve günümüzde ev/yuva olan Uşak evleri, nesnel/boyutsal olarak da ekslibris zemini üzerinde geniş bir alanı kaplamaktadır. Bu alan özellikle evlerin yaşamın merkezinde yer alması kavramına da bir gönderme olarak değerlendirilebilinir. $\mathrm{P}=$ Fotografik çogaltma/Photographic reproduction ve CRD = Bilgisayarla çogaltma/Computer reproduced design (Ekslibris, 2015) teknikleri kullanılarak özgün ekslibris üretimleri yapılmıştır. Bu üretimlerde ekslibrisin ayrılmaz bir parçası olan tipografik unsurlar da ev odaklı tasarımların içine yerleştirilmiştir.

\subsection{Muna Silav'ın suluboya çalışmaları}

Resim sanatının dallarından biri olan suluboya tekniğinin tarihi çok eski dönemlere dayanmaktadır. Doğal parlaklığı ve hızlı uygulama tekniğinden dolayı mimari eskizlerde tercih edilen suluboya ile çalışmalar renklendiğinde, hayallerden gerçeğe yaklaşılır. Su ile boyanın birleşimi ve firça darbelerinin kâğıt üzerindeki hareketleri suluboya resim sanatını ortaya çıkarmıştır. Eski çağlardan itibaren resim, insanın duygularını, düşüncelerini, hayallerini ifade ederek aklın ve duyguların birleşmesini sağlamıştır (Silav, 2014). 

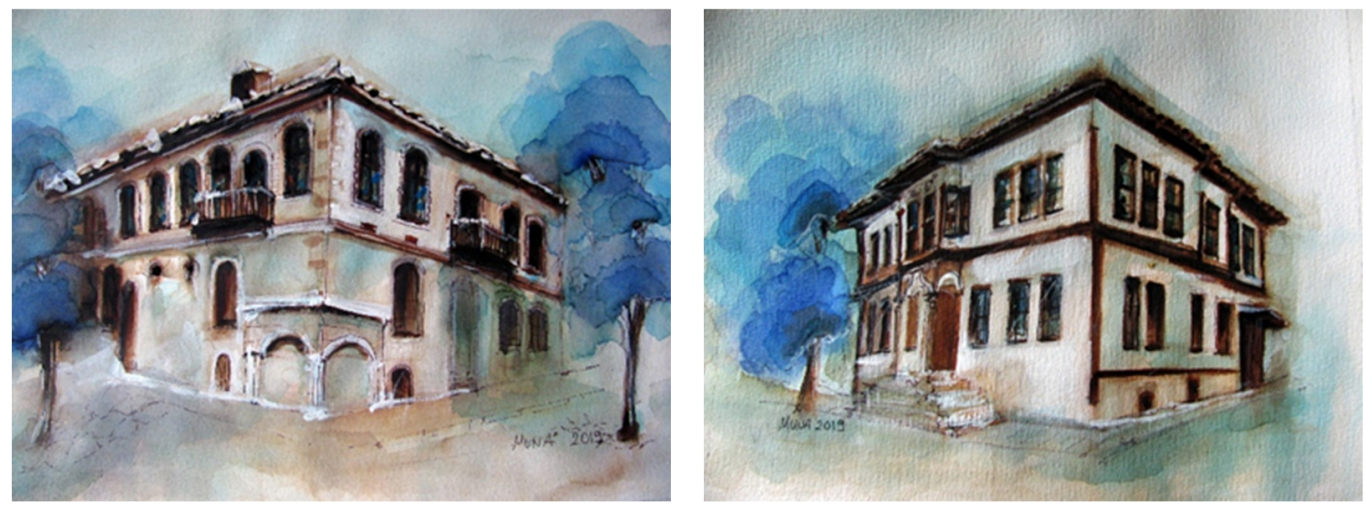

Görsel 6. Muna Silav, Uşak evleri, suluboya, $23 \times 29$ cm, 2019

Geleneksel Uşak Evleri suluboya çalışmaları, taşınmaz kültür varlıklarını belgeleme amacıyla gerçekleştirilmiştir. Suluboya tekniği kullanılarak oluşturulan bu çalışmalarda, geleneksel kent dokusuna ait değerlerin yansıtılması amaçlanmıştır. Öncellikle Uşak evlerinin mimari ve yapısal özellikleri araştırılmıştır. Yapılan araştırmalar sonrasında Uşak il merkezinde yer alan, tarihi ve mimari değeri olan, geleneksel evler konu olarak belirlenmiştir. Geleneksel konutların halen özgün işlevini yaşatması, tarihi kent dokusunun devamlılığının gözlemlendiği yapıların eskizlerinde hızlı çalışmayı sağlayan suluboya tekniği kullanılmıştır. Saydamlık ve şeffaflık etkisini güçlendiren, 1şık ve gölge oyunları ile bireysel yorumlar yer almıştır.
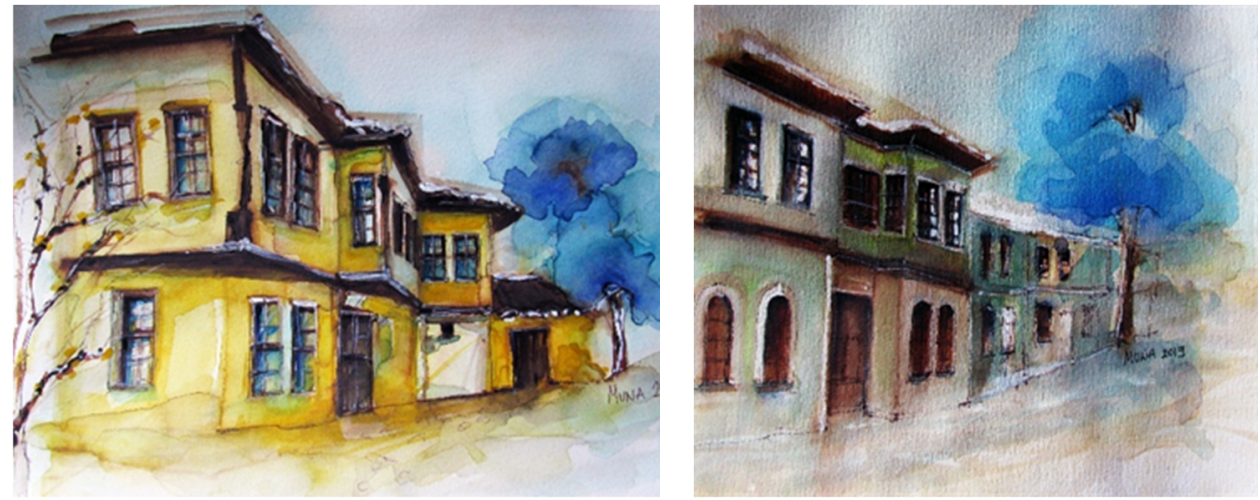

Görsel 7. Muna Silav, Uşak evleri, suluboya, 24x31 cm ve 23x29 cm, 2019

Çalışmalarda perspektif etkinin güçlenmesi, derinliği ve duyarlığı vurgulamak için mavi renk kullanılmıştır. Uşak Evleri serisinde yer alan çalışmalarda yapıların orijinal rengine bağlı kalarak dönemin abartıdan uzak naif yaşam tarzını vurgulamak amacı ile pastel renkler tercih edilmiştir.
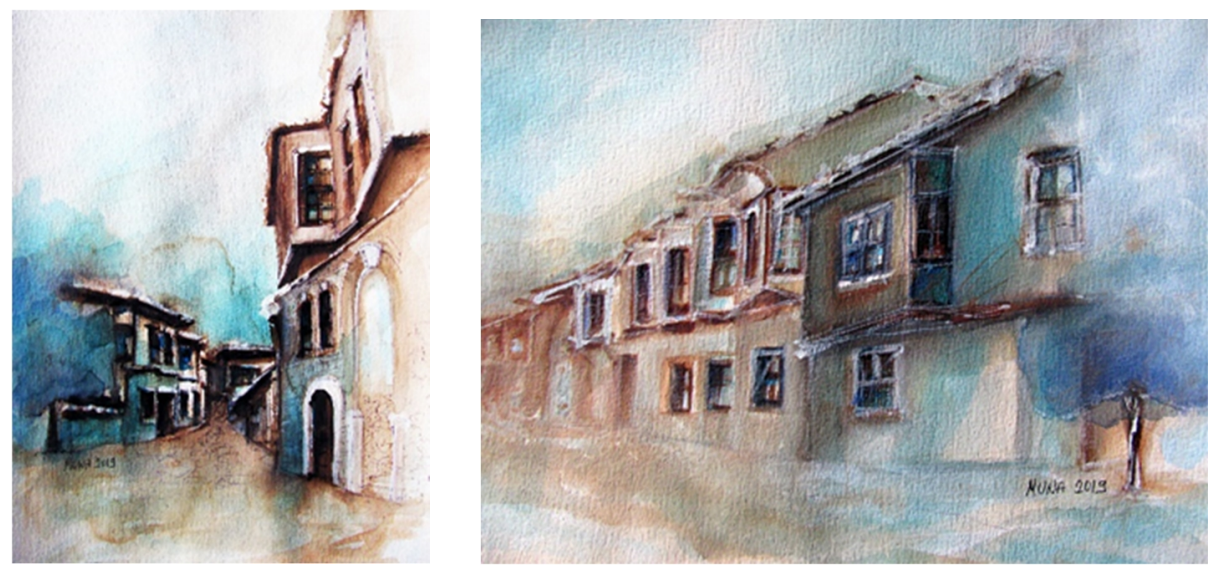

Görsel 8. Muna Silav, Uşak evleri, suluboya, 25x32 cm ve 22×29 cm, 2019 


\section{Sonuç}

Uşak ili, Anadolu'nun eski yerleşim merkezlerindendir. Günümüzde de estetik ve tarihi yönü ile öne çıkan yapılardan; evler, camiler, hanlar, hamamlar tarihi kent dokusunu yaşatmaktadır. Geleneksel Uşak evleri, sahip oldukları mimari karakterleriyle, kent tarihinin yaşayan birer belgesidir ve kent dokusunun önemli yapı elemanları olarak koruma altındadır. Anadolu'nun diğer kentlerinde olduğu gibi ev kavramının oluşumunda yörenin doğal koşullarının yanı sıra inançların, geleneklerin, sosyal hayatın ve kültürün yansıması oldukça önemlidir. Bu yansıma, kentsel mirası koruma çalışmalarının ve özgün kentsel kimliğin sürdürülebilirliğinin, sanat yolu ile sağlanması açısından etkin yöntemlerdendir.

Uşak ilinin tarihi ve kültürel miras değerlerinin sivil mimarlık örnekleri üzerinden incelendiği bu çalışmada; belgeleme niteliği taşıyan Uşak evlerinin Naile Salman Çevik'in ekslibris ve Muna Silav’ın suluboya çalışmalarında bireysel/sanatsal söylemleri aracılığı ile tarihi dokunun, estetik değerinin anlaşılması ve bu değerler sisteminin gelecek nesillere aktarılması bakımından oldukça önemli bir etkiye sahiptir.

\section{Kaynakça}

Akdeniz, H. (1995). Plastik sanatlarda günümüz sanat eğilimlerinin düşünsel dayanakları ve bunun çağdaş Türk sanatına yansıması üzerine bir değerlendirme. Anadolu Sanat, 3, 9-34.

Antmen, A. (2008). 20.yüzyıl batı sanatında akımlar. İstanbul: Sel Yayıncılık.

Ayan, M. (2007). Sosyolojik açıdan özgün baskıresim sanatının bugünkü durumu ile ilgili profesyonel sanatçıların görüşlerinin incelenmesi (Doktora tezi). Marmara Üniversitesi, İstanbul. YÖK tez veri tabanından erişildi (Tez No: 206230).

Ekim, E. (2012). Türk evinde yaşam alanı: avlu (Yüksek lisans tezi). İstanbul Teknik Üniversitesi, İstanbul. YÖK tez veri tabanından erişildi (Tez No: 350544).

Eldem, S. H. (1984). Türk evi: Osmanlı dönemi. İstanbul: Türkiye Anıt Çevre Turizm Değerlerini Koruma Vakfi.

Fırıncı, M. (2013). Dijital çağda geleneksel baskı resim ve teknikler arası geçiş (melezleşme). Anadolu Üniversitesi Sanat ve Tasarım Dergisi, 4(4), 127-135.

Gürboğa, F. (1999). Uşak hanları ve ticaret yapıları (Yüksek lisans tezi). Atatürk Üniversitesi, Erzurum. YÖK tez veri tabanından erişildi (Tez No: 89944).

Kaderli, L. (2014). Kültürel miras koruma yaklaşımlarının tarihsel gelişimi. Türkiye Bilimler Akademisi Kültür Envanteri Dergisi, 12, 29-41.

Karahan, Ü. O. (2015). Eskiçăgda Uşak ve çevresi (en eski devirlerden M.S 395 yılına kadar) (Doktora tezi). Selçuk Üniversitesi, Konya. YÖK tez veri tabanından erişildi (Tez No: 393119).

Kaynar, A. (2006). Kaynak ve dayanaklarlyla exlibris ve bir örnek sanatçı: Hasip Pektaş (Yüksek lisans tezi). Mustafa Kemal Üniversitesi, Hatay. YÖK tez veri tabanından erişildi (Tez No: 191034).

Kuban, D. (2002). Mimarlık kavramları: tarihsel perspektif içinde mimarlığın kuramsal sözlüğüne giriş. İstanbul: Yapı Endüstri Merkezi Yayınları.

Kuban, D. (2017). Türk ahşap konut mimarisi 17.-19. yüzyıllar. İstanbul: Türkiye İş Bankası Kültür Yayınları.

Kurtar, C., \& Somuncu, M. (2013). Kentsel kültürel mirasın korunması ve sürdürülebilirliği: Ankara hamamönü örneği. Ankara Araştırmaları Dergisi, 1(2), 35-47.

Küçükerman, Ö. (1995). Anadolu mirasında Türk evleri. İstanbul: T.C. Kültür Bakanlığı Yayınları.

Özdemir Dağıstan, M. Z. (2005). Türkiye'de kültürel mirasın korunmasına kısa bir bakış. TMMOB Planlama Dergisi, 1, 20-25.

Pektaş, H. (2014). Exlibris. Ankara: İED.

Pektaş, H. (2015, 11 Mart). Eklibris baskı teknikleri ve simgeleri [Blog yazısı]. Erişim adresi: http://www.aed.org.tr/tr/ekslibris-baski-teknikleri-ve-simgeleri

Sayan, Y. (1997). Uşak evleri. Ankara: Kültür Bakanlığı Yayınları.

Severin, M. F. (1949). Making a bookplate. London\&New York: England: The Studio Publications.

Silav, M. (2014). Mimari eskizlerde suluboya. Ankara: Pelikan Yayıncılık.

Solak, E. (2001). XX. yüzyılda Uşak kazası (Yüksek lisans tezi). Afyon Kocatepe Üniversitesi, Afyon. YÖK tez veri tabanından erişildi (Tez No: 101752). 
T.C. Orman ve Su İşleri Bakanlığı (2013). Uşak ili doğa turizmi master planı (2013-2023). Doğa Koruma ve Milli Parklar Genel Müdürlüğü V. Bölge Müdürlüğü. Erişim adresi: http:/bolge5.ormansu.gov.tr

Taylan, F. N. (2013). Uşak halı motiflerinin seramik yüzeylerde uygulanabilirliği ve kişisel uygulamalar (Yüksek lisans tezi). Uşak Üniversitesi, Uşak. YÖK tez veri tabanından erişilldi (Tez No: 344661).

Tweed, C., \& Shutherland, M. (2007). Built cultural heritage and sustainable urban development. Landscape and Urban Planing, 83, 62-69.

Uysal, Ö. N. (2007). Geleneksel Türk evi iç mekân kurgusunun incelenmesi ve Süleymaniye bölgesi örnekleri analizi (Yüksek lisans tezi). Mimar Sinan Güzel Sanatlar Üniversitesi, İstanbul. YÖK tez veri tabanından erişildi (Tez No: 213937).

Yalçın, S. (2012). Sanayi devriminden günümüze özgün baskıresim sanatının önemi ve yükseköğretimde özgün baskiresim sanat eğitiminin sosyo-kültürel yansıma açısından incelenmesi (Yüksek lisans tezi). Marmara Üniversitesi, İstanbul. YÖK tez veri tabanından erişildi (Tez No: 319505).

Yürekli, H., \& Yürekli, F. (2007). Türk evi: gözlemler ve yorumlar. İstanbul: YEM Yayınları.

Zakar, L., ve Eyüpgiller, K. K. (2015). Mimari restorasyon koruma teknik ve yöntemler. İstanbul: Ömür Matbaacilik.

\section{Görsel Kaynakçası}

Görsel 1. Gürsoy, E. (2016). Uşak’taki tarihi evlerde çıkmalar. Karabük Üniversitesi Sosyal Bilimler Enstitüsü Dergisi, 6(2), 349-361. http://dx.doi.org/10.14230/joiss249

Görsel 2. Gürsoy, E. (2016). Uşak’taki tarihi evlerde çıkmalar. Karabük Üniversitesi Sosyal Bilimler Enstitüsü Dergisi, 6(2), 349-361. http://dx.doi.org/10.14230/joiss249

Görsel 3. Naile Salman Çevik arşivinden alınmıştır.

Görsel 4. Naile Salman Çevik arşivinden alınmıştır.

Görsel 5. Naile Salman Çevik arşivinden alınmıştır.

Görsel 6. Muna Silav arşivinden alınmıştır.

Görsel 7. Muna Silav arşivinden alınmıştır.

Görsel 8. Muna Silav arşivinden alınmıştır. 